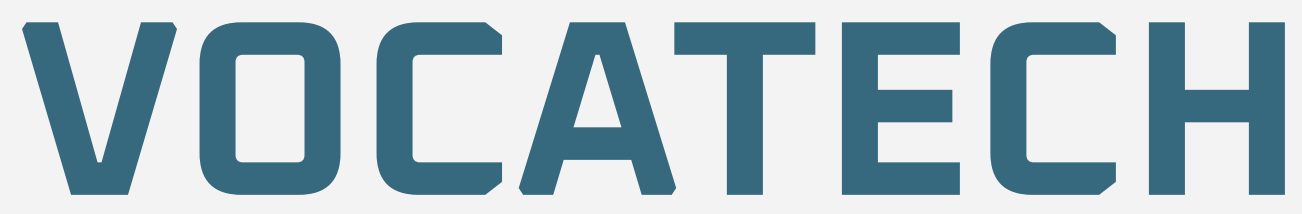

VOCATIONAL EDUCATION AND TECHNOLGY JOURNAL

Biannual

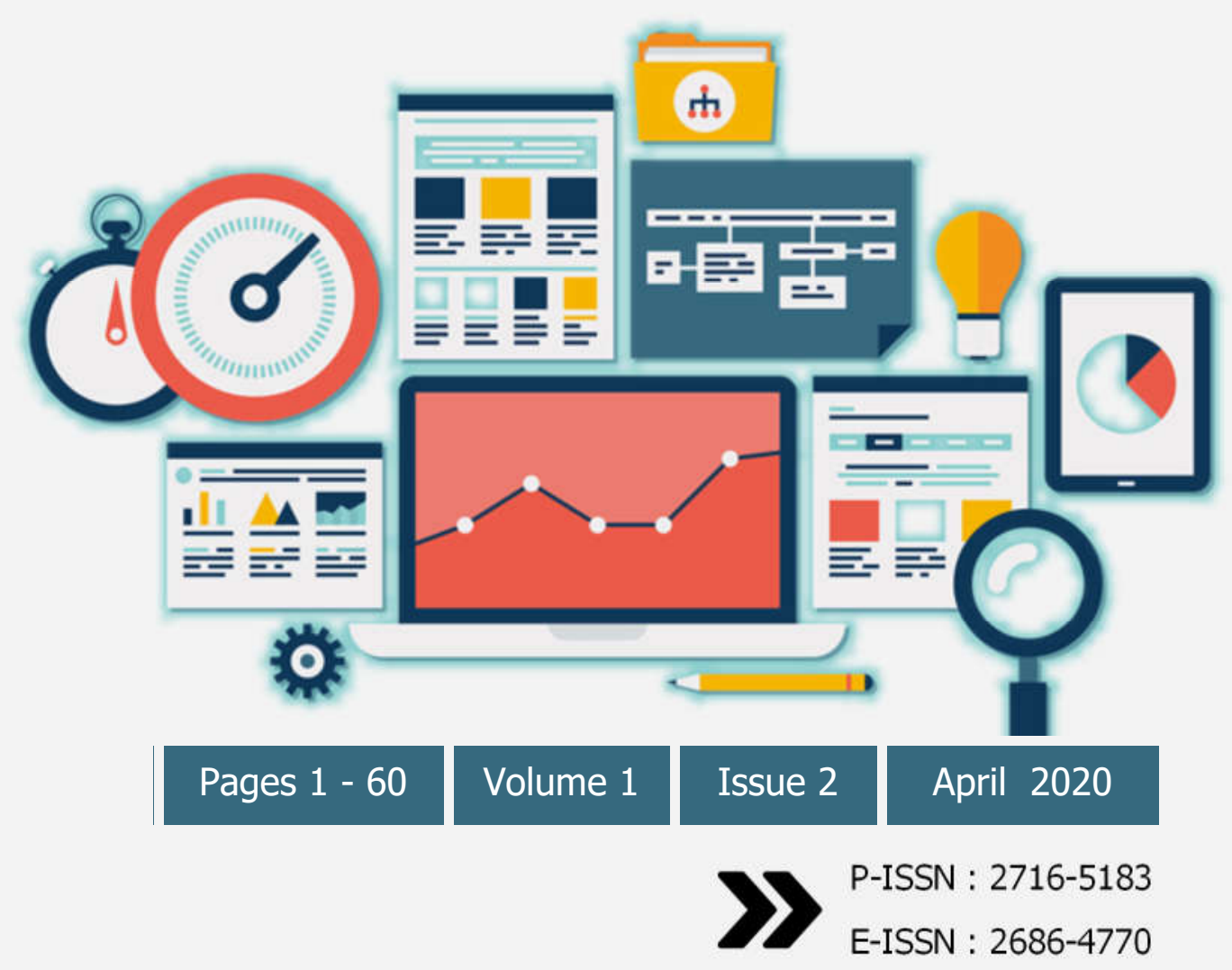

Published By: Unit Penelitian, Pengabdian Masyarakat dan Penjaminan Mutu Akademi Komunitas Negeri Aceh Barat

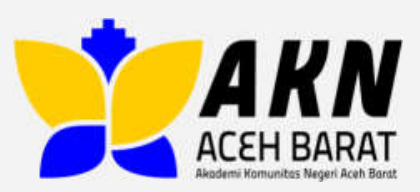




\section{P-ISSN : 2716-5183 \\ E-ISSN : 2686-4770

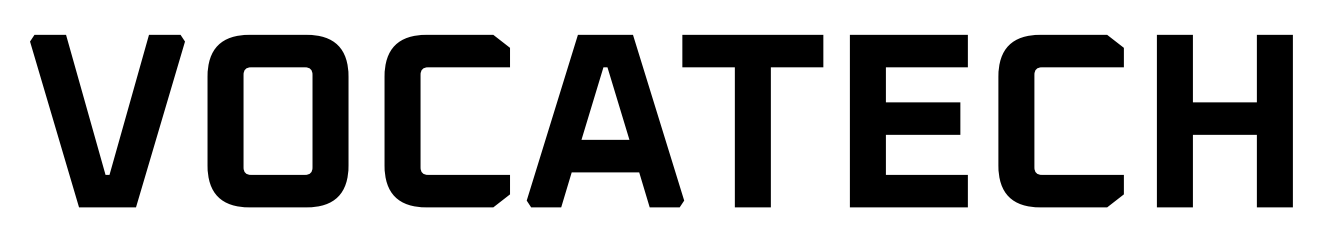

VOCATIONAL EDUCATION AND TECHNOLGY JOURNAL

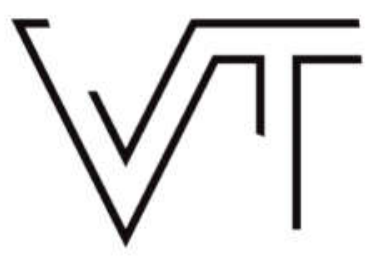

\section{Editorial Team}

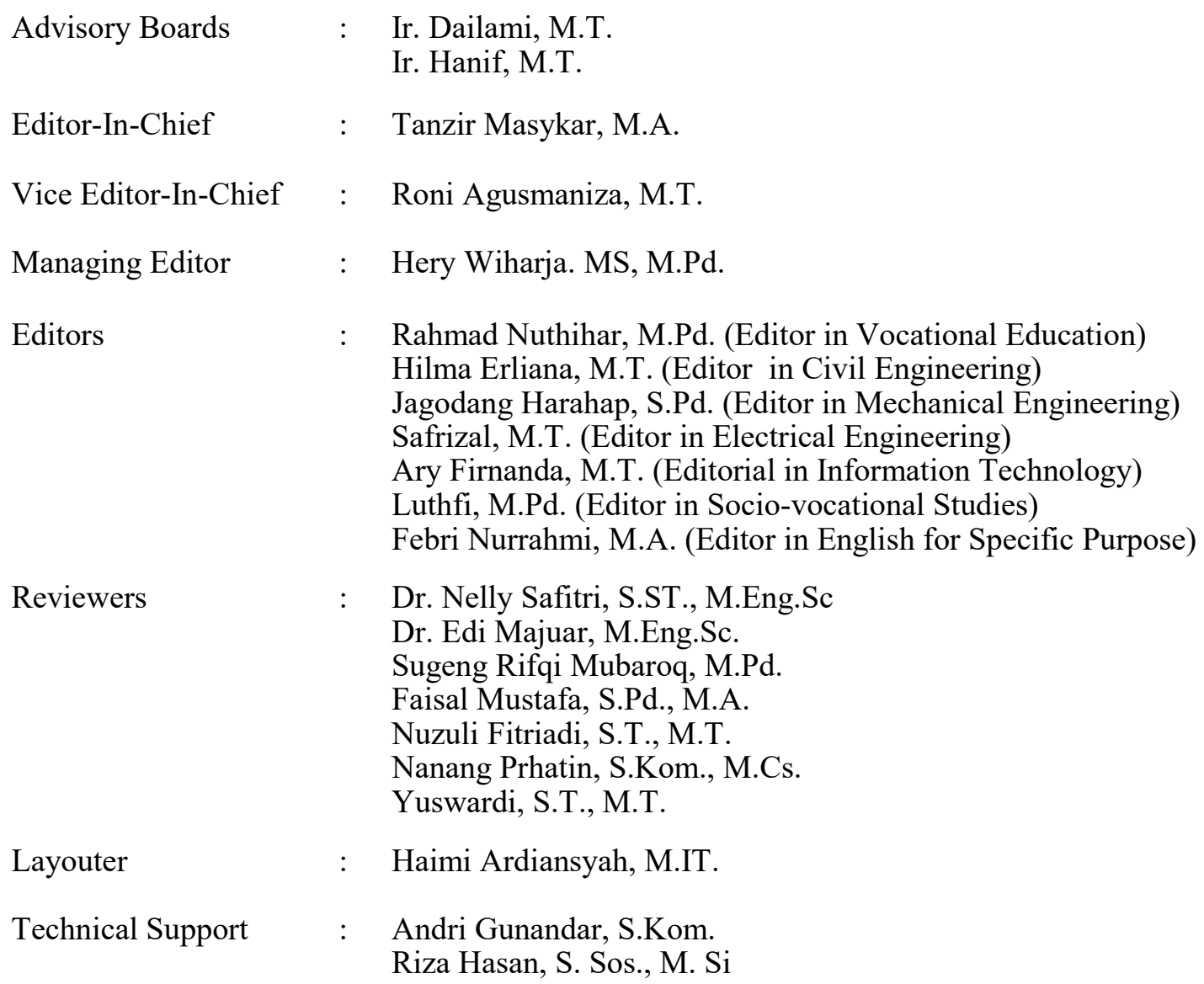

\section{Alamat Redaksi (Journal Address)}

Unit Penelitian, Pengabdian Masyarakat dan Penjaminan Mutu

Akademi Komunitas Negeri Aceh Barat

Komplek STTU Alue Peunyareng, Ujong Tanoh Darat, Meureubo, Kabupaten Aceh Barat, Aceh 23615, Indonesia

Website: http://ojs.aknacehbarat.ac.id/index.php/vocatech/index

Email:vocatech@akanacehbarat.ac.id 


\section{(2) \\ E-ISSN : 2686-4770

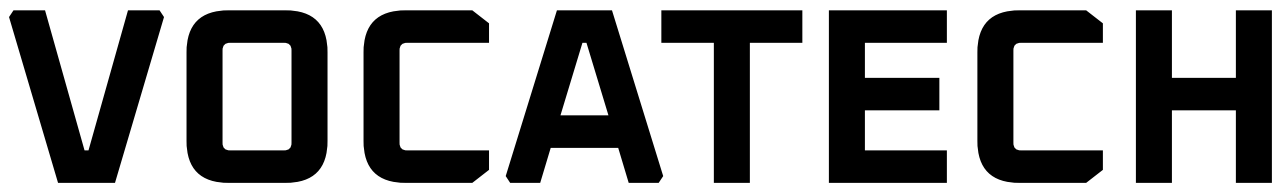 \\ VOCATIONAL EDUCATION AND TECHNOLGY JOURNAL}

\section{DAFTAR ISI (TABLE OF CONTENT)}

Pengaruh $R O E, D E R$, dan EPS Terhadap Harga Saham pada Emiten Syariah Sektor Barang

Konsumsi di BEI

—Dwi Meilvinasvita, Safaruddin, Yuliana—-

Penerapan General English dan English For Specific Purposes di Perguruan Tinggi Khususnya pada Pendidikan Vokasi

\section{—Rena Juliana, Reni Juliani-}

Pengaruh Penggunaan Kapasitor Bank pada Penyulang Kota di Pt. PLN (Persero) Rayon

Meulaboh Kota

-Haimi Ardiansyah-

Desain Alat Uji Impak Jatuh Bebas untuk Pengujian Baja Struktur

—Dailami, Hamdami, Samsul Bahri-

Analisis Kinerja Angkutan Kota dalam Provinsi di Provinsi Aceh Berdasarkan Pendekatan Load

Factor

—Ruhdi Faisal, Cut Mutiawati , Alfi Salmannur-

Klasifikasi Kematangan Buah Tomat dengan Variasi Model Warna Menggunakan Support Vector

Machine

\section{-Nica Astrianda-}

Implementasi Algoritma K-Mean dalam Pengelompokan Data Kecelakaan di Kabupaten Kediri

—Adimas Ketut Nalendra, M. Mujiono, Rafika Akhsani, Adiguna Sasama Wahyu U.- 


\title{
KLASIFIKASI KEMATANGAN BUAH TOMAT DENGAN VARIASI MODEL WARNA MENGGUNAKAN SUPPORT VECTOR MACHINE
}

\author{
Nica Astrianda \\ Akademi Komunitas Negeri Aceh Barat, Aceh
}

\begin{abstract}
Tomato ripeness classification has been done manually through direct visual observation. However, manual classification is highly influenced by operator subjectivity so that on certain conditions, the classification process is not consistent. The development of information technology allows the identification of the ripeness level of tomatoes based on the characteristics of color with the help of computers. In this study Tomato fruit is classified by histogram color image input obtained from the capture result. This is done by changing all the colors in the image of the RGB color model (Red, Green, Blue) into several different color models ie HSV color model (Hue, Saturation, Value), CIElab color model and YCBCR color model. The obtained color model will be used as training data using SVM (Support Vector Machine) so that the system is able to classify the ripeness of tomato fruit later. The image processing process of this research is done using matlab. After being analyzed manually using 20 data as training, 54 data as data testing got success rate classification of tomato fruit ripeness using Support Vector Machine is $100 \%$ by using CIElab color model.
\end{abstract}

Keywords:

Support Vector Machine; CIElab; HSV; YCbCr; Ripeness of Tomato

\begin{abstract}
Abstrak
Klasifikasi kematangan tomat telah dilakukan secara manual melalui pengamatan visual langsung. Namun, klasifikasi manual sangat dipengaruhi oleh subjektivitas operator sehingga pada kondisi tertentu, proses klasifikasi tidak konsisten. Perkembangan teknologi informasi memungkinkan identifikasi tingkat kematangan tomat berdasarkan karakteristik warna dengan bantuan komputer. Dalam penelitian ini buah tomat diklasifikasikan berdasarkan input gambar berwarna histogram yang diperoleh dari hasil tangkapan. Hal ini dilakukan dengan mengubah semua warna pada gambar model warna $R G B$ (Red, Green, Blue) menjadi beberapa model warna yang berbeda yaitu model warna $H S V$ (Hue, Saturation, Value), model warna CIElab dan model warna YCBCR. Model warna yang diperoleh akan digunakan sebagai data pelatihan menggunakan SVM (Support Vector Machine) sehingga sistem mampu mengklasifikasikan kematangan buah tomat. Proses pengolahan citra pada penelitian ini dilakukan dengan menggunakan matlab. Setelah dianalisis secara manual menggunakan 20 data sebagai data pelatihan, 54 data sebagai data pengujian mendapatkan klasifikasi tingkat keberhasilan kematangan buah tomat menggunakan Support Vector Machine adalah 100\% dengan menggunakan model warna CIElab.
\end{abstract}

Kata Kunci:

Support Vector Machine; CIElab; HSV; YCbCr; Kematangan Tomat.

Received:23 March, 2020; Revised: 27 March, 2020; Accepted: 31 March 2020

DOI: https://doi.org/10.38038/vocatech.v1i2.27

Corresponding author:

Nica Astrianda, Program Studi Instalasi Jaringan Listrik, Akademi Komunitas Negeri Aceh Barat, Komplek STTU Alue Peunyareng, Ujong Tanoh Darat, Meureubo, Kabupaten Aceh Barat, Aceh 23615, Indonesia.

Email: nica.astrianda@aknacehbarat.ac.id

Citation in APA Sty: Astrianda, N., (2020). Klasifikasi Kematangan Buah Tomat Dengan Variasi Model Warna Menggunakan Support Vector Machine. VOCATECH: Vocational Education and Technology Journal, Vol. 1 (2), 44-51. 


\section{PENDAHULUAN}

Di zaman dengan teknologi yang berkembang dengan sangat pesat seperti saat ini, banyak inovasi- inovasi yang telah lahir untuk memudahkan manusia. Kebutuhan manusia juga semakin tergantung pada teknologi di bidang komunikasi, pendidikan, bahkan di bidang perkebunan. Hingga saat ini teknologi yang membantu manusia di perkebunan kurang berkembang. Buah-buahan adalah komoditas yang menguntungkan karena keanekaragaman varietas dan didukung oleh iklim yang sesuai, menghasilkan varietas buah-buahan yang menarik (Permadi, 2019).

Buah tomat adalah salah satu produk hortikultura yang memiliki pasar prospektif. Penanganan pasca panen memainkan peran penting dalam menentukan kualitas tomat, terutama pemilihan dan penentuan kualitas kegiatan. Sejauh ini, pemilihan dan penentuan aktivitas kualitas tomat dilakukan secara manual, sehingga menghasilkan produk yang kurang seragam. Karena hasil seleksi manual kurang memuaskan, perlu metode untuk memilih dan mengklasifikasikan tomat dengan baik (Riska, 2015).

Pengembangan metode pengolahan citra untuk mengklasifikasikan kematangan tomat menggunakan komputer. Sebelum sistem pemrosesan gambar diterapkan, identifikasi kematangan tomat sebagian besar dilakukan secara manual oleh manusia. Identifikasi kematangan tomat manual memiliki banyak kelemahan yang disebabkan oleh banyak faktor, seperti kelelahan, kurang motivasi, pengalaman, kemahiran dan sebagainya. Untuk mengatasi masalah ini, pengembangan teknologi informasi memungkinkan identifikasi kematangan buah dan bahkan deteksi jenis buah dengan bantuan komputer. Safrizal (2019) juga pernah melakukan pembuatan applikasi computer pengenalan tulisan huruf jawi dengan menggunakan fitur sudut.
Karakteristik yang dapat membedakan bagaimana tomat berubah menjadi masak ialah dari bentuk, warna, ukuran dan teksturnya. Fitur warna pada tomat adalah karakteristik yang paling mudah digunakan untuk membedakan tomat masak dan tomat belum masak, karena warna dapat dilihat secara langsung tidak perlu bersentuhan dengan tekstur. Banyak penelitian sebelumnya telah dilakukan dalam mengklasifikasikan tomat (Astrianda \& Mohamad, 2017).

Beberapa penelitian menggunakan metode pengenalan pola, alat, perangkat lunak, dan bahasa pemrograman untuk mengenali tingkat kematangan tomat dan buah lain selain tomat seperti pepaya, nanas, dan apel. Dalam beberapa penelitian, fitur warna diekstraksi menggunakan model warna RGB, HSV, YCbCr, CIELAB, CMYK dan lainnya. Sebagian besar fitur diekstraksi menggunakan model warna RGB dan juga dengan berbagai metode seperti Multi-SVM, Jaringan Syaraf Tiruan, Backpropagation, Watershed, K-Means, Euclidian Distance, Mahalanobis dan lainnya. Penelitian sebelumnya tentang klasifikasi kematangan tomat menghasilkan tingkat akurasi yang bervariasi. Kesimpulan dari penelitian sebelumnyapun menghasilkan akurasi yang berbeda, sebagian besar peneliti berfokus pada mengidentifikasi kematangan tomat berdasarkan warna menggunakan satu model warna, secara umum, hanya model warna RGB yang digunakan dalam penelitian (Sari, 2013). Karena itulah, dalam penelitian klasifikasi ini kematangan tomat menggunakan perangkat lunak matlab untuk mengolah data. Algoritma yang digunakan adalah Support Vector Machine dengan menggunakan beberapa model warna yang berbeda yaitu HSV, CIELAB, dan YCBCR. 


\section{STUDI PUSTAKA}

Salah satu produk pertanian terpenting dengan tingkat produksi yang tinggi adalah Tomat. Sebagai akibatnya, petani tomat berkewajiban untuk mengklasifikasikan tingkat kematangan tomat sehingga dapat mengurangi atau meminimalkan risiko penguraian tomat. Proses kematangan tomat hanya memakan waktu yang singkat (Riska \& Subekti, 2016). Oleh karena itu, tingkat klasifikasi kebenaran Kematangan buah tomat sangat penting. Tujuan klasifikasi adalah untuk mendeskripsikan kelas yang telah ditentukan untuk setiap instance tertentu. Dengan melakukan ini, kita dapat memahami bagaimana data dapat digunakan untuk memprediksi perilaku kasus baru (Ghazali, Subha, \& Burhannudin, 2018).

Banyak penelitian yang telah dipelajari sebelumnya menggunakan model warna RGB sebagai referensi untuk karakteristik warna dalam mengidentifikasi kematangan buah. Ini masih dapat ditingkatkan dengan bereksperimen dengan mengubah model warna RGB menjadi model warna lain. Model warna yang menjadi referensi bagi peneliti dalam penelitian ini adalah model warna HSV, YCbCr, dan CIELAB. Pemilihan model warna adalah karena beberapa penelitian sebelumnya menggunakan model warna sebagai referensi menghasilkan tingkat akurasi yang baik dan berbeda dalam uji kematangan buah. Ini membuat peneliti ingin membandingkan beberapa model warna ini dengan metode Support Vector Machine untuk mengidentifikasi ketepatan kematangan tomat.

\section{A. Model Warna RGB}

Model warna RGB merupakan singkatan dari Red Green Blue. Model warna RGB juga disebut additive color atau warna pencahayaan karena apabila RGB dikombinasikan maka akan menghasilkan warna putih. RGB digunakan dalam input device dan output device elektronik seperti scanner dan display monitor.

\section{B. Model Warna HSV}

Model warna HSV mendefinisikan warna dalam kaitannya dengan Hue, Saturation, dan Value. Hue menyatakan warna asli, seperti merah, ungu, dan kuning. HUE digunakan untuk memisahkan antara warna dan menentukan warna kemerahan, kehijauan, dan sebagainya dari cahaya. Hue dikaitkan dengan panjang gelombang cahaya. Saturation menyatakan tingkat kemurnian suatu warna, yang menunjukkan seberapa banyak warna putih diterapkan pada warna tersebut. Nilai adalah atribut yang menyatakan jumlah cahaya yang diterima mata terlepas dari warna (Rakhmawati, 2013).

\section{Model Warna YCbCr}

YCbCr merpakan model warna yang terdiri dari tiga buah matriks dua dimensi. $\mathrm{YCbCr}$ memisahkan citra ke dalam 2 komponnen, yaitu komponen luminance dan komponen warna komponen luminance pada $\mathrm{YCbCr}$ dipresentasikan oleh komponen $\mathrm{Y}$, sedangkan komponen warna dipresentasikan pada komponen $\mathrm{Cb}$ dan $\mathrm{Cr}$ (Ananto \& Murinto, 2015). Pada dasarnya model warna ini dikembangkan untuk mengantisipasi perkembangan informasi berbasiskan video, sehingga model warna ini banyak sekali digunakan pada video digital. Secara umum model warna $\mathrm{YCbCr}$ dapat dikatakan merupakan bagian dari ruang warna televisi dan transmisi video. Ada dua model warna yang mirip dengan $\mathrm{YCbCr}$ yaitu YUV dan YIQ, perbedaannya $\mathrm{YCbCr}$ merupakan sistem warna digital sedangkan YUV dan YIQ merupakan sistem warna analog.

\section{Model Warna CIElab}

CIELAB merupakan model warna 3 dimensi, model warna ini hanya dapat digambarkan apabila dalam ruang tiga dimensi, dan apabila diambil irisan komponen "a" dan "b", maka akan mendapatkan diagram chromaticity "a" dan diagram chromaticity"b". model warna memiliki makna dari setiap dimensi yang dibentuk yaitu (Sinaga, 2019) : 
a) Dimensi "L" yang mendeskripsikan kecerahan warna, (0 untuk warna hitam dan $\mathrm{L}=100$ untuk putih).

b) Dimensi "a" mendeskripsikan warna hijaumerah, nilai negatif "a" mengidentifikasikan sebagai warna hijau; "a" positif mengindikasikan warna merah,

c) Dimensi "b" untuk warna biru-kuning, nilai negatif "b" mengindikasikan warna biru dan sebaliknya "b" positif mengindikasikan warna kuning.

\section{E. $S V M$}

SVM merupakan salah satu metode klasifikasi yang baik dalam pemecahan masalah untuk dua kelas, penelitian yang melibatkan kasus dibidang kehidupan nyata cenderung mencakup kasus multiclass, sehingga pada penelitian yang terdiri dalam dua kelas diusulkan metode SVM untuk menyelesaikan masalah tersebut terutama dalam bidang pertanian (Arief, 2019).

\section{METODE}

Proses penelitian yang diusulkan diperkenalkan sebagai kerangka kerja penelitian. Kerangka kerja ini terdiri dari empat langkah utama, yang dibahas secara berurutan. Ini adalah pengambilan data sampel, ekstraksi fitur warna dari RGB ke YCbCr, CIElab dan HSV, pencocokan fitur menggunakan SVM, dan hasil klasifikasi kematangan buah tomat.

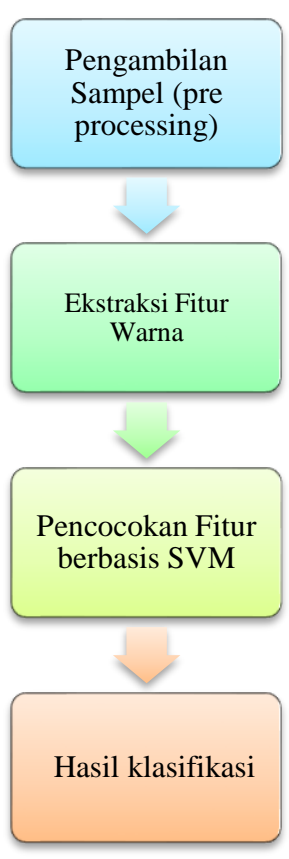

Gambar 1. Gambar Kerja Klasifikasi kematangan Tomat.

\section{A. Pengambilan Data Sampel}

Data yang digunakan berupa gambar buah tomat matang dan mentah. Pengambilan sampel tomat dilakukan di luar ruangan dengan menggunakan kamera smartphone. Pemotretan dilakukan dari atas tomat dengan jarak $25 \mathrm{~cm}$ dari objek. Peneliti melakukan penelitian dengan pengambilan sampel tomat sebagai sampel untuk mengidentifikasi kematangan. Sampel data dalam penelitian ini adalah 74 gambar yang dibagi menjadi dua kelas tingkat kematangan yaitu kelas matang dan kelas mentah. Data sampel dibagi menjadi dua bagian data yaitu data uji dan data pelatihan. Data uji terdiri dari 54 data yang terdiri dari 20 gambar kelas matang dan 34 kelas mentah, sedangkan data pelatihan sebanyak 20 data yang terdiri dari 10 gambar kelas matang dan 10 gambar kelas mentah.

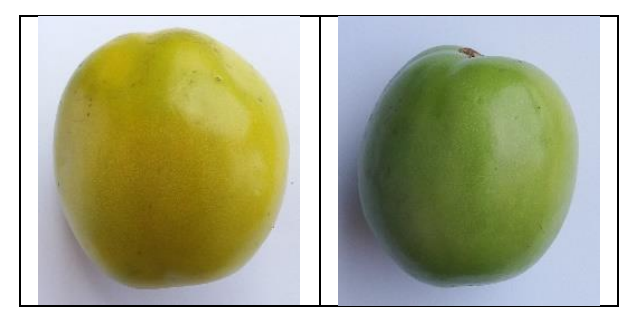




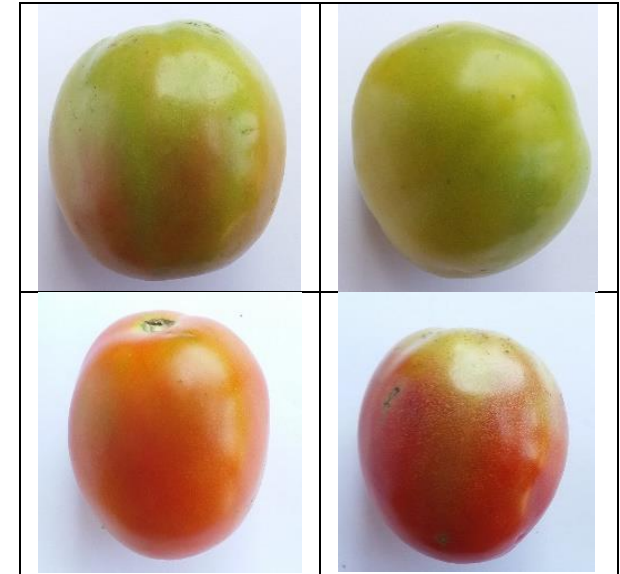

Gambar 2. Data Sampel

Ketika merencanakan penelitian ini, derau pada gambar, kompleksitas latar belakang harus dipertimbangkan. Tujuan utama preprocessing adalah untuk memastikan peningkatan kualitas gambar yang diproses. Ini membantu membuat fase identifikasi dan pengenalan selanjutnya lebih mudah.

Adapun preprocessing yang digunakan dalam penelitian ini meliputi:

1. Menangkap citra nyata tomat,

2. Mengidentifikasi jumlah kemunculan setiap tingkat abu-abu dalam citra tomat. Dalam pencitraan area gelap, level abu-abu pada histogram akan mengelompok di sebelah kiri, citra area terang di sebelah kanan dan area dengan kontras signifikan, level abu-abu akan menyebar,

3. Menghilangkan noise yang disebabkan oleh interferensi optik pada perangkat akuisisi dan tidak disengaja yang disebabkan untuk pengumpulan data yang tidak tepat,

4. dikonversi menjadi gambar biner untuk memudahkan membedakan antara latar belakang dengan latar depan, area putih adalah objek area latar depan tomat untuk dihitung nilai fitur warna. Area hitam di luar objek adalah latar belakang.

5. Mengembalikan gambar RGB dari hasil segmentasi.

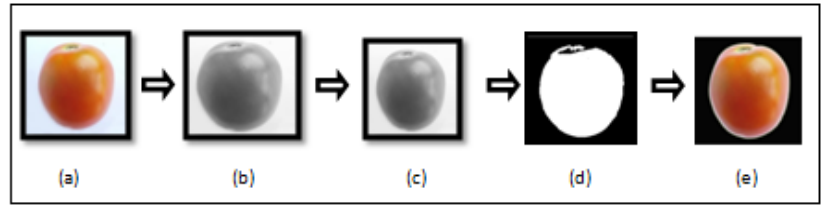

Gambar 3. Tahapan Preprocessing.

\section{B. Ektraksi Fitur Warna}

Fitur ekstraksi yang digunakan dalam penelitian ini adalah fitur warna. Karena itu, dalam penelitian ini, warna menjadi sangat penting dalam menentukan tingkat kematangan tomat. Ada tiga model warna yang akan digunakan dalam penelitian ini yaitu HSV, YCbCr, dan CIElab. Proses ekstraksi fitur dimulai dengan mengubah ruang warna gambar RGB (hasil akuisisi gambar) ke HSV (Hue Saturation Value), RGB ke YCbCr, dan RGB ke CIElab.

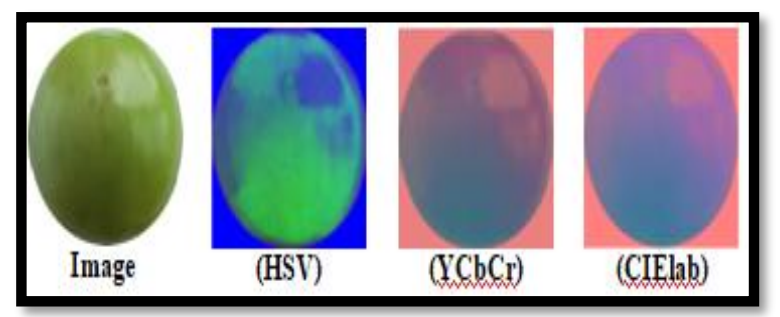

Gambar 4. Ekstraksi Fitur Warna

Hasil ekstraksi ini berupa nilai histogram yang disimpan kedalam Microsoft Excel.

\section{B. Pencocokan fitur}

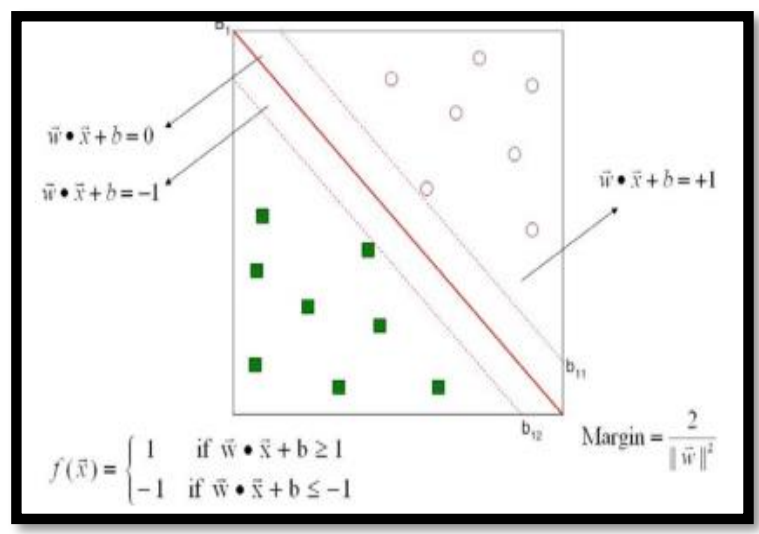

Gambar 5. Model SVM

Gambar 4. menunjukkan model Support Vector Machine di mana proses pemetaan nonlinear digunakan untuk mengubah data pelatihan menjadi 
dimensi yang lebih tinggi. Pada dimensi baru akan dicari hyperplane pemisah linier yang optimal. Separator hyperplane terbaik antara kedua kelas dapat ditemukan dengan mengukur margin hyperplane dan mencari titik maksimum. Margin adalah jarak antara hyperplane dan pola terdekat dari setiap kelas. Pola terdekat disebut vektor dukungan. Kelebihan SVM dibandingkan dengan metode lain terlihat dalam kemampuannya untuk menemukan hyperplane terbaik yang akan memisahkan dua kelas pada ruang fitur untuk mendapatkan hasil klasifikasi terbaik.

Perintah yang digunakan dalam sintaks MATLAB untuk menentukan set pelatihan dan set pengujian adalah sebagai berikut:

\section{$[$ Train, Test $]=$ crossvalind $($ Method, Group, $P)$}

Grup adalah vektor pengelompokan yang mendefinisikan kelas dari setiap pengamatan yang dalam penelitian ini adalah kelompok kelas masak "1" dan kelas tidak masak "2". Pembagian kelompok tergantung pada jenis metode yang digunakan. Untuk melakukan klasifikasi pola yang menggunakan dua tahap pelatihan dan pengujian.

SVM di Matlab mengklasifikasikan data menjadi dua kelas. Ada dua fungsi yang digunakan, yaitu svmtrain untuk pelatihan dan svmclassify untuk mengklasifikasikan data berdasarkan pelatihan sebelumnya.

Perintah yang digunakan dalam sintaks MATLAB untuk pelatihan klasifikasi SVM adalah sebagai berikut:

\section{SVMStruct $=$ svmtrain $($ Training, Group $) ;$}

Pelatihan tentang SVM menggunakan data Pelatihan. Pelatihan data adalah matriks data yang berasal dari kedua Grup. Informasi pelatihan classifier SVM termasuk dalam SVMStruct, di mana informasi berikut ada bias, Fungsi Kernel dan Data Skala (ayak dan skala). Bias adalah intersepsi dari hyperplane yang memisahkan dua kelompok dalam tabel data yang dinormalisasi.
Fungsi symtrain menggunakan metode optimisasi untuk mengidentifikasi Support Vector $s_{i}$, bobot $\alpha_{i}$, dan bias $b$ yang digunakan untuk mengklasifikasikan vektor $\mathrm{x}$ berdasarkan persamaan berikut;

$$
c=\sum_{i} a_{i} k\left(s_{i}, x\right)+b
$$

di mana $\mathrm{k}$ adalah fungsi kernel. Dalam kasus kernel linear, $\mathrm{k}$ adalah produk titik. Jika $\mathrm{c} \geq 0$, maka $\mathrm{x}$ diklasifikasikan sebagai anggota kelompok pertama, jika tidak maka itu diklasifikasikan sebagai anggota kelompok kedua. Setelah pelatihan selesai, proses selanjutnya adalah menguji hasil pelatihan. Perintah yang digunakan dalam sintaks MATLAB untuk pengujian SVM adalah sebagai berikut:

\section{Class = svmclassify $($ svmstruct, testing $) ;$}

Svmclassify mengklasifikasikan setiap baris pengujian data menggunakan informasi dalam struktur SVM (svmstruct).

Metode validasi yang digunakan dalam penentuan data pelatihan dan pengujian adalah metode bertahan. Dalam metode ini, data asli dipartisi menjadi dua set terpisah yang disebut set pelatihan dan set pengujian. Model klasifikasi kemudian dibangun berdasarkan set pelatihan dan hasilnya kemudian dievaluasi menggunakan set pengujian. Akurasi setiap metode klasifikasi dapat diperkirakan berdasarkan keakuratan yang diperoleh dari set pengujian. Proporsi antara set pelatihan dan set pengujian tidak mengikat tetapi untuk membuat variasi dalam model tidak terlalu besar, ditentukan bahwa proporsi set pelatihan lebih kecil dari set pengujian.

\section{HASIL DAN PEMBAHASAN}

Dalam penelitian ini hasil penelitian klasifikasi kematangan tomat menggunakan model warna berbeda berdasarkan Support Vector Machine dibagi menjadi dua kelas, yaitu kelas masak (1) dan kelas belum masak (2). Dari 53 data pengujian 
yang menjadi akurasi validasi data diperoleh hasil yang diperlihatkan pada table 1 .

Tabel 1. Hasil Validasi Sistem

\begin{tabular}{|c|c|c|c|c|}
\hline Gambar & Kelas & HSV & YCBCR & CIELAB \\
\hline 1 & 1 & 1 & 1 & 1 \\
\hline 2 & 1 & 1 & 1 & 1 \\
\hline 3 & 1 & 1 & 1 & 1 \\
\hline 4 & 1 & 2 & 1 & 1 \\
\hline 5 & 1 & 1 & 1 & 1 \\
\hline 6 & 1 & 1 & 1 & 1 \\
\hline 7 & 1 & 1 & 1 & 1 \\
\hline 8 & 1 & 1 & 1 & 1 \\
\hline 9 & 1 & 1 & 1 & 1 \\
\hline 10 & 1 & 1 & 2 & 1 \\
\hline 11 & 1 & 1 & 1 & 1 \\
\hline 12 & 1 & 1 & 1 & 1 \\
\hline 13 & 1 & 1 & 1 & 1 \\
\hline 14 & 1 & 1 & 1 & 1 \\
\hline 15 & 1 & 1 & 2 & 1 \\
\hline 16 & 1 & 1 & 2 & 1 \\
\hline 17 & 1 & 1 & 1 & 1 \\
\hline 18 & 1 & 1 & 1 & 1 \\
\hline 19 & 1 & 1 & 2 & 1 \\
\hline 20 & 1 & 1 & 1 & 1 \\
\hline 21 & 2 & 2 & 2 & 2 \\
\hline 22 & 2 & 2 & 2 & 2 \\
\hline 23 & 2 & 2 & 1 & 2 \\
\hline 24 & 2 & 2 & 2 & 2 \\
\hline 25 & 2 & 2 & 2 & 2 \\
\hline 26 & 2 & 2 & 2 & 2 \\
\hline 27 & 2 & 2 & 2 & 2 \\
\hline 28 & 2 & 2 & 1 & 2 \\
\hline 29 & 2 & 2 & 2 & 2 \\
\hline 30 & 2 & 1 & 1 & 2 \\
\hline 31 & 2 & 2 & 2 & 2 \\
\hline 32 & 2 & 2 & 1 & 2 \\
\hline 33 & 2 & 2 & 2 & 2 \\
\hline 34 & 2 & 2 & 2 & 2 \\
\hline 35 & 2 & 2 & 2 & 2 \\
\hline 36 & 2 & 2 & 1 & 2 \\
\hline 37 & 2 & 2 & 2 & 2 \\
\hline 38 & 2 & 2 & 2 & 2 \\
\hline 39 & 2 & 2 & 2 & 2 \\
\hline 40 & 2 & 2 & 1 & 2 \\
\hline 41 & 2 & 2 & 1 & 2 \\
\hline 42 & 2 & 2 & 2 & 2 \\
\hline 43 & 2 & 2 & 1 & 2 \\
\hline 44 & 2 & 2 & 2 & 2 \\
\hline 45 & 2 & 2 & 2 & 2 \\
\hline 46 & 2 & 2 & 2 & 2 \\
\hline 47 & 2 & 2 & 2 & 2 \\
\hline 48 & 2 & 1 & 1 & 2 \\
\hline 49 & 2 & 2 & 1 & 2 \\
\hline 50 & 2 & 2 & 2 & 2 \\
\hline 51 & 2 & 2 & 2 & 2 \\
\hline 52 & 2 & 2 & 2 & 2 \\
\hline 53 & 2 & 2 & 2 & 2 \\
\hline
\end{tabular}

Dari Tabel 1. Terlihat jelas perbedaan hasil keakuratan validasi setiap model warna. Ini membuktikan penggunaan model warna yang tepat diperlukan dalam menentukan tingkat keakuratan sistem. Hasil persentasi akurasi diperlihatkan pada tabel 2. Model warna HSV menghasilkan tingkat akurasi $95 \%$, YCbCr sebesar $74 \%$ dan CIElab sebesar $100 \%$.

Tabel 2. Persentasi Akurasi

\begin{tabular}{lllll}
\hline $\begin{array}{l}\text { Model } \\
\text { Warna }\end{array}$ & Benar & Salah & Akurasi & $\begin{array}{l}\text { Waktu } \\
\text { Tempuh }\end{array}$ \\
\hline HSV & 51 & 3 & $95 \%$ & $4.491 \mathrm{~s}$ \\
YCBCR & 40 & 14 & $74 \%$ & $4.098 \mathrm{~s}$ \\
CIELAB & 53 & 0 & $100 \%$ & $4.248 \mathrm{~s}$ \\
\hline
\end{tabular}

Dari hasil yang telah didapatkan dalam table 1 dan 2 menunjukkan kelebihan dan kelemahan penggunaan model warna dengan hasil yang berbeda. Adapun setiap model warna menunjukan kelemahan dan kelebihannya tersendiri. Untuk model warna HSV mempunyai kelebihan dan kelemahan mampu mengidentifikasi buah masak lebih akurat dibandingkan dengan buah tidak masak. Untuk model warna YCBCr kurang mampu mengidentifikasi dibandingkan dengan dua model warna yang lain. Dan untuk model warna CIElab mampu mengidentifikasi dengan sangat akurat baik kelas masak maupun tidak masak.

\section{KESIMPULAN}

Pada Penelitian klasifikasi kematangan buah tomat dengan variasi model warna ( $\mathrm{HSV}, \mathrm{YCbCr}$ dan CIElab) menggunakan Support Vector Mahine menghasilkan hasil yang akurat dengan menggunakan model warna CIElab. Untuk penelitian selanjutnya disarankan untuk menggunakan metode dan model warna yang lain sebagai perbandingan hasil keakuratan sistem.

\section{DAFTAR PUSTAKA}

Ananto, I. D., \& Murinto. (2015). Aplikasi Pengolahan Citra Mendeteksi Kualitas Cabai Berdasarkan Tingkat Kematangan Menggunakan Transformasi Warna YCbCr. Jurnal Informartika UAD, 9(2), 283-293. Arief, M. (2019). Klasifikasi Kematangan Buah 
Jeruk Berdasarkan Fitur Warna

Menggunakan Metode SVM. Jurnal Ilmu

Komputer Dan Desain Komunikasi Visual, 4(1), 9-16.

Astrianda, N., \& Mohamad, F. S. (2017). Ripeness

Identification of Tomato Using Different

Color Models Based on Neural

Networklevenberg-Marquardt. World Applied

Sciences Journal, 35(Lm), 57-61.

Ghazali, Eko K., Subha, Galuh M., Burhannudin,

M. I. N. (2018). Aplikasi Kematangan Tomat

Berdasarkan Warna dengan Metode Linear

Discriminant Analysis (LDA).

Https://Docplayer.Info/31373581-Aplikasi-

Kematangan-Tomat-Berdasarkan-Warna-

Dengan-Metode-Linear-Discriminant-

Analysis-Lda.Html.

Permadi, B. E. (2019). Rancang bangun alat sortir

kematangan buah belimbing berdasarkan

ukuran dan warna dengan mikrokontroler arduino.

Rakhmawati, R. P. (2013). Sistem Deteksi Jenis Bunga Menggunakan Nilai Hsv Dari Citra Mahkota Bunga. Universitas Stikubank, Semarang.

Riska, S. Y. (2015). Klasifikasi Level Kematangan

Tomat Berdasarkan Perbedaan Perbaikan Citra Menggunakan Rata-Rata RGB Dan Index Pixel. Jurnal Ilmiah Teknologi Informasi Asia, 9(2), 18-26.

Riska, S. Y. R., \& Subekti, P. (2016). Klasifikasi Level Kematangan Buah Tomat Berdasarkan Fitur Warna Menggunakan Multi-Svm. Jurnal Ilmiah Informatika, 1(1).

Safrizal, S. (2019). Pengenalan Karakter Jawi Tulisan Tangan Menggunakan Fitur Sudut. VOCATECH: Vocational Education and Technology Journal, 1, 1-4.

Sari, R. T. (2013). Perbandingan metode jaringan syaraf tiruan backpropagation dan algoritma pencocokan dalam mengidentifikasi kematangan tomat buah berdasarkan ciri warna rgb. Yogyakarta: Fakultas Sains dan Teknologi UIN Sunan Kalijaga Yogyakarta.

Sinaga, A. S. (2019). SEGMENTASI RUANG WARNA L*a*b. Jurnal Mantik Penusa, 3(1), 43-46.

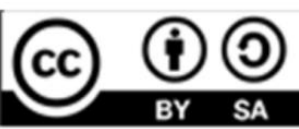

Copyright (C) 2020

Vocatech: Vocational Education and Technology Journal This works is licensed under a Creative Common Attribution-ShareAlike 4.0 